\title{
THE EFFECT OF TRANEXAMIC ACID INJECTION ON HEMOGLOBIN LEVEL, ALBUMIN LEVEL, AND PAIN ON PATIENT RECEIVING TOTAL KNEE REPLACEMENT
}

\author{
Dwikora Novembri Utomo ${ }^{*}$, Teddy Heri Wardhana ${ }^{1}$, Ahmad Hannan Amrullah², \\ Hamzah $^{3}$ \\ ${ }^{1}$ Staff of Orthopaedic and Traumatology Department, Faculty of Medicine, Universitas \\ Airlangga, Dr Soetomo General Hospital, Surabaya \\ ${ }^{2}$ Resident of Orthopaedic and Traumatology Department, Faculty of Medicine, Universitas \\ Airlangga, Dr Soetomo General Hospital, Surabaya \\ ${ }^{3}$ Staff of Anesthesiology and Reanimation Department, Faculty of Medicine, Universitas \\ Airlangga, Dr Soetomo General Hospital, Surabaya \\ *Corresponding Author: Dwikora Novembri Utomo, Staff of Orthopaedic and Traumatology \\ Department, Faculty of Medicine, Universitas Airlangga, Jl. Mayjen Prof. Dr. Moestopo 6-8, \\ Surabaya. \\ E-mail: dwikora_utomo@yahoo.com
}

\begin{abstract}
ABSTRAK
Latar belakang: Tingginya jumlah penderita osteoarthritis lutut menyebabkan arthroplasty semakin sering dilakukan. Prosedur operasi Total Knee Replacement (TKR) berisiko terjadi perdarahan yang masif. Perdarahan dapat mempengaruhi kadar albumin dan terjadinya tekanan intra kompartemen pada saraf. Penggunaan asam traneksamat merupakan salah satu cara yang dapat dilakukan untuk mengurangi perdarahan.

Tujuan: Membuktikan efek pemberian asam traneksamat intravena pada pasien yang akan menjalani prosedur operasi TKR.
\end{abstract}

Metode Penelitian: Penelitian dilakukan secara eksperimental menggunakan data primer pemeriksaan laboratorium yang diperoleh sebelum dan sesudah operasi pada pasien yang akan dilakukan operasi TKR sejak April 2017.

Hasil: Terdapat 64 pasien yang menjalani operasi TKR. Rerata hemoglobin sebelum operasi pada kelompok asam traneksamat dan tanpa asam traneksamat sejumlah 13,06 $\pm 1,46 \mathrm{~g} / \mathrm{dl}$ dan $12,44 \pm 0,87 \mathrm{~g} / \mathrm{dl}$. Rerata hemoglobin setelah operasi menjadi 10,29 $\pm 1,14 \mathrm{~g} / \mathrm{dl}$ dan 9,16 $\pm 0,97$ $\mathrm{g} / \mathrm{dl}$. Pada kelompok yang mendapat asam traneksamat, 32 orang (100\%) melaporkan skor VAS pascaoperasi yang rendah, tidak membutuhkan transfusi darah, dan tidak membutuhkan transfusi albumin. Kelompok yang tidak mendapatkan asam traneksamat, 32 orang (100\%) skor VAS pascaoperasi yang sedang, 4 orang $(12,5 \%)$ membutuhkan transfusi darah, dan 3 orang $(9,4 \%)$ membutuhkan transfusi albumin.

Kesimpulan: Hasil penelitian ini menunjukkan bahwa kelompok yang diberikan asam traneksamat memiliki kadar hemoglobin setelah operasi yang lebih tinggi dibanding kelompok yang tidak diberi asam traneksamat, tidak ada perbedaan kadar albumin setelah operasi pada kedua kelompok, pemberian asam traneksamat akan menurunkan jumlah kehilangan darah, menurunkan derajat nyeri, dan berkurangnya kebutuhan transfusi darah setelah operasi TKR.

Kata kunci: Total Knee Replacement, asam traneksamat, hemoglobin, albumin, VAS score 


\begin{abstract}
Background: The high number of knee osteoarthritis cases could lead arthroplasty more frequent. Total Knee Replacement (TKR) surgery procedure is at risk of massive bleeding. Bleeding can affect albumin levels and the onset of intra-compartment pressure on the nerves. The use of tranexamic acid could be done to reduce bleeding.

Objective: Proving the effect of intravenous tranexamic acid administration on patients who will undergo TKR surgery.

Methods: The experiment was conducted experimentally using primary laboratory data obtained before and after surgery in patient which will be performed TKR operation starting from April 2017.

Result: There are 64 patients who had undergone total knee replacement surgery. The mean preoperative hemoglobin in the tranexamic acid group and without tranexamic acid was $13.06 \pm 1.46 \mathrm{~g} / \mathrm{dl}$ and $12.44 \pm 0.87 \mathrm{~g} / \mathrm{dl}$. The mean hemoglobin after surgery was $10.29 \pm 1.14 \mathrm{~g} / \mathrm{dl}$ and $9.16 \pm 0.97 \mathrm{~g} / \mathrm{dl}$. In the group receiving tranexamic acid, $32(100 \%)$ reported low postoperative VAS scores, did not require blood transfusions and did not require albumin transfusion. Groups not receiving tranexamic acid, 32 (100\%) moderate postoperative VAS scores, 4 people $(12.5 \%)$ required the blood transfusion, and $3(9.4 \%)$ required transfusion of albumin.

Conclusion: The results of this study showed that the group given tranexamic acid had higher hemoglobin levels after surgery than the untreated group of tranexamic acid; there was no difference in albumin levels after surgery in both groups; the administration of tranexamic acid will decrease the amount of blood loss, decrease the degree of pain, and decrease the need for blood transfusions after total knee replacement surgery.
\end{abstract}

Keywords: total knee replacement, tranexamic acid, hemoglobin, albumin, VAS score

\title{
PENDAHULUAN
}

Prosedur arthroplasty atau joint replacement telah berhasil mengurangi keluhan, meningkatkan kualitas hidup, serta meningkatkan produktivitas dari pasien dengan arthritis. Tatalaksana ini hemat biaya dan aman terhadap keluhan nyeri lutut akibat osteoarthritis, juga memiliki efek pemulihan fungsi fisik yang sederhana dan cepat pada pasien yang tidak respon terhadap pengobatan konservatif. Salah satu tindakan joint replacement yang paling sering dilakukan adalah Total Hip Replacement (THR) dan Total Knee Replacement (TKR). World Health Organization (WHO) memperkirakan bahwa $37,4 \%$ penduduk dunia yang berusia lebih dari 70 tahun menderita osteoarthritis lutut dan $12,1 \%$ di antaranya adalah osteoarthritis lutut simtomatik dengan derajat 2 atau lebih berdasarkan klasifikasi Kellgren-Lawrence. ${ }^{1}$ WHO memasukkan osteoarthritis lutut ke dalam daftar Global Burden of Disease. ${ }^{2}$ Di Indonesia didapatkan angka kejadian osteoartritis lutut pada pria adalah sebesar $15,5 \%$ dan $12,7 \%$ pada wanita, yang mana sekitar $98 \%$ osteoarthritis derajat 4 akan menjalani operasi TKR. $^{3}$ Sejalan dengan peningkatan jumlah kasus osteoarthritis, maka jumlah prosedur TKR menyumbang $35 \%$ dari seluruh penyakit artritis yang 
membutuhkan rawat inap. Sejak tahun 1992 hingga 2011, jumlah prosedur TKR meningkat hingga $2,7 \% .^{4}$

Operasi TKR adalah operasi besar dalam bidang orthopedi dengan potensi kehilangan darah yang signifikan dikarenakan adanya release soft tissue secara extensive dan pemotongan tulang. Total kehilangan darah pada operasi TKR dapat mencapai 800-1800 ml..$^{5}$ Diperkirakan sekitar 15 juta transfusi dilakukan tiap tahunnya dan sekitar 20\% mengakibatkan efek samping. Berbagai cara dapat dilakukan untuk mengurangi perdarahan, antara lain pemakaian torniquet dan agen-agen antifibrinolitik seperti aprotinin, asam traneksamat, dan asam aminokaproat (EACA). ${ }^{6,7}$

Asam traneksamat semakin banyak digunakan dalam bedah orthopedi karena efikasi, keamanan, dan biaya yang terjangkau. Beberapa studi telah menunjukkan manfaat asam traneksamat dalam prosedur TKR yaitu mengurangi hilangnya darah perioperatif dan kebutuhan transfusi tanpa meningkatkan risiko komplikasi tromboembolik. ${ }^{8-8}$ Beberapa penelitian meta analisis melaporkan penggunaan asam traneksamat pada operasi TKR efektif menurunkan kebutuhan transfusi darah, menurunkan total blood loss dan tidak ada perbedaan kejadian deep vein thrombosis dan pulmonary embolism. ${ }^{9-10}$
Terdapat beberapa efek yang dapat terjadi akibat perdarahan. Salah satu akibat lain dari terjadinya perdarahan pascaoperasi TKR adalah peningkatan tekanan intra kompartemen yang dapat mengkompresi saraf dan mengakibatkan nyeri. Kompartemen sindrom terjadi ketika tekanan dalam kompartemen anatomis meningkat terus hingga perfusi aliran darah pada lapisan jaringan menurun, dimana ini mengakibatkan penekanan pada saraf dan iskemia jaringan, yang terlihat dari nyeri. Intensitas nyeri yang ditimbulkan dapat diukur secara klinis dengan menggunakan Visual Analog Scale (VAS). ${ }^{9}$ Sejumlah besar albumin juga dapat hilang akibat perdarahan. Perdarahan menyebabkan hilangnya konstituen dari whole blood termasuk eritrosit, albumin, dan globulin. ${ }^{11}$

Berdasarkan hal tersebut di atas, maka penelitian ini bertujuan untuk mengetahui apakah ada hubungan pemberian asam traneksamat pada pasien yang menjalani prosedur TKR terhadap kadar hemoglobin, kadar albumin, total blood loss, derajat nyeri, dan kebutuhan transfusi pascaoperasi.

\section{METODOLOGI PENELITIAN}

Penelitian ini merupakan suatu penelitian eksperimental pada pasien yang akan menjalani operasi TKR mulai bulan April 2017 dengan pemberian injeksi asam 
traneksamat. Penelitian ini menggunakan data primer berupa evaluasi laboratorium. Penelitian ini telah dinyatakan laik etik oleh Komite Etik RSUD Dr. Soetomo Surabaya, dan telah mendapatkan sertifikat Kelaikan Etik dengan nomor 0876/KEPK/XII/2018.

Kriteria inklusi pada penelitian ini mencakup semua pasien yang direncanakan untuk menjalani operasi TKR dengan dan tanpa asam traneksamat sejak bulan April 2017, pasien yang bersedia dilakukan pemeriksaan dan wawancara, pasien dengan hasil laboratorium preoperatif normal (hemoglobin, hemostasis, fungsi liver, fungsi ginjal, dan albumin), Pasien yang tidak mendapat pengobatan NSAID, aspirin atau obat mempengaruhi pembekuan darah dalam 2 minggu sebelum operasi, serta pada pasien dengan diagnosis osteoarthritis stadium 4 .

Kriteria eksklusi pada penelitian ini mencakup pasien yang memiliki gangguan kognitif yang tidak memungkinkan dilakukan pemeriksaan dan wawancara, mengalami penyakit gangguan pembekuan darah, mengalami serangan infark miokard dalam 6 bulan terakhir, angina tidak stabil, stenosis katup aorta atau mitral, riwayat stroke, hipertensi yang tidak diobati, riwayat penyakit thromboemboli, kelainan perdarahan atau dalam pengobatan warfarin. Teknik pengambilan sampel dilakukan dengan metode systematic random sampling. Pasien yang memenuhi kriteria penelitian dibagi menjadi grup pasien yang mendapatkan injeksi asam traneksamat dan tidak mendapatkan injeksi asam traneksamat. Pasien diperiksa kadar hemoglobin, hemostasis, albumin, fungsi hati, dan fungsi ginjal sebelum dilakukan operasi.

Pasien dioperasi oleh operator yang sama, dengan teknik operasi yang sama dan jenis implan yang sama. Asam traneksamat diberikan sebanyak $15 \mathrm{mg} / \mathrm{kgBB}$ pada waktu 15 menit sebelum torniquette dipompa (150 mmHg + tekanan sistolik pasien). Pasien dibius dengan Combine Spinal and Epidural Anastesia (CSEA). Durante operasi, dilakukan pengukuran kehilangan darah menggunakan suction dan kasa yang sudah dipakai. Regulasi cairan diusahakan tidak menggunakan transfusi darah. Pasien diberikan kembali injeksi asam traneksamat 3 jam setelah operasi dan 6 jam setelah operasi dengan dosis $15 \mathrm{mg} / \mathrm{kgBB}$. Pasien mendapat obat analgetik yang sama pada pascaoperasinya.

Selanjutnya pasien diperiksa laboratorium darah kadar hemoglobin dan kadar albumin 24 jam pascaoperasi. Kebutuhan transfusi darah dipenuhi berdasarkan hasil pengukuran kadar hemoglobin 24 jam pascaoperasi dan jenis darah yang diberikan adalah Packed Red Blood Cell. Selanjutnya, diukur total blood 
loss pasien dengan menjumlahkan volume kehilangan darah durante operasi dengan menghitung volume darah dalam drainage $(\mathrm{mL})$ dan jumlah kasa yang digunakan dan volume kehilangan darah pada pascaoperasi diukur dari drainage $(\mathrm{mL})$ setelah 24 jam pascaoperasi. Selanjutnya diukur derajat nyeri 24 jam pascaoperasi. $^{12}$ Ada tidaknya komplikasi post operasi dievaluasi pada hari $1-3$ post operasi. $^{12}$

Data yang diperoleh pada penelitian ini selanjutnya dianalisis dan ditampilkan dalam bentuk tabel dan grafik. Selanjutnya data diolah dan dilakukan analisa menggunakan uji independent t-test untuk mengetahui perbedaan terhadap kadar hemoglobin, total blood loss, kadar albumin Analisa Man Whitney juga dilakukan untuk mengetahui perbedaan derajat nyeri antara grup yang mendapatkan injeksi asam traneksamat intravena preoperatif dan tidak mendapatkan injeksi asam traneksamat intravena preoperatif. Data diolah menggunakan program SPSS versi 16.0.

\section{HASIL DAN PEMBAHASAN}

Pada penelitian ini didapatkan data sejumlah 64 pasien yang menjalani operasi TKR sejak April 2017 di salah satu rumah sakit di Surabaya. Pasien dibagi menjadi 2 kelompok yang terdiri dari 32 pasien yang mendapatkan terapi asam traneksamat dan 32 pasien yang tidak mendapatkan terapi asam traneksamat.

Subyek penelitian yang mendapat terapi asam traneksamat sejumlah 10 orang $(31,2 \%)$ laki-laki dan wanita 22 orang $(68,8 \%)$ dengan rerata umur $65,37 \pm 9,82$ tahun. Subyek penelitian yang tidak mendapat terapi asam traneksamat sejumlah 11 orang $(34,4 \%)$ laki-laki dan wanita 21 orang $(65,6 \%)$ dengan rerata umur 63,84 \pm 7,35 .

Hasil pemeriksaan hemoglobin sebelum operasi pada kelompok asam traneksamat sejumlah $13,06 \pm 1,46$ dan pada kelompok yang tidak mendapatkan asam traneksamat sejumlah $12,44 \pm 0,87$. Hasil pemeriksaan albumin sebelum operasi pada kelompok asam traneksamat sejumlah 3,91 \pm 0,26 dan pada kelompok yang tidak mendapatkan asam traneksamat sejumlah $3,87 \pm 0,30$.

Hasil pemeriksaan rerata hemoglobin setelah operasi pada kelompok asam traneksamat sejumlah 10,29 $\pm 1,14$ $\mathrm{mg} / \mathrm{dl}$ dan pada kelompok yang tidak mendapatkan asam traneksamat sejumlah $9,16 \pm 0,97 \mathrm{mg} / \mathrm{dl}$.

Rerata albumin pada kelompok asam traneksamat menjadi 3,20 $\pm 0,28 \mathrm{mg} / \mathrm{dl}$ dan pada kelompok yang tidak mendapatkan asam traneksamat menjadi 3,10 $\pm 0,40 \mathrm{mg} / \mathrm{dl}$. Rerata jumlah kehilangan darah pada 
kelompok asam traneksamat sebanyak 219,38 $\pm 25,89 \mathrm{~mL}$ dan pada kelompok yang tidak mendapatkan asam traneksamat sebanyak $377,50 \pm 46,14 \mathrm{~mL}$.

Pengukuran skor VAS pascaoperasi pada kelompok asam traneksamat, didapatkan skor rendah sejumlah 32 orang (100\%). Pada kelompok yang tidak mendapatkan asam traneksamat, didapatkan skor sedang sejumlah 32 orang (100\%).

Pada penghitungan kebutuhan transfusi darah pada kelompok asam traneksamat, didapatkan yang tidak membutuhkan transfusi darah sejumlah 32 orang (100\%). Pada kelompok yang tidak mendapatkan asam traneksamat, yang membutuhkan transfusi darah sejumlah 4 orang $(12,5 \%)$ dan yang tidak membutuhkan transfusi darah sejumlah 28 orang $(87,5 \%)$.

Pada penghitungan kebutuhan transfusi albumin, kelompok asam traneksamat yang tidak membutuhkan transfusi albumin sejumlah 32 orang (100\%). Pada kelompok yang tidak mendapatkan asam traneksamat, didapatkan 3 orang $(9,4 \%)$ membutuhkan transfusi albumin dan 29 orang (90,6\%) tidak membutuhkan transfusi albumin.

Tabel 1. Distribusi frekuensi karakteristik pasien Total Knee Replacement

\begin{tabular}{lcc}
\hline \multicolumn{1}{c}{ Karakteristik Pasien } & \multicolumn{2}{c}{ Total (\%) } \\
& $\begin{array}{c}\text { Injeksi Asam } \\
\text { Traneksamat }\end{array}$ & $\begin{array}{c}\text { Tanpa Injeksi Asam } \\
\text { Traneksamat }\end{array}$ \\
\hline Jenis Kelamin & $10(31,2 \%)$ & $11(34,4 \%)$ \\
Laki-laki & $22(68,8 \%)$ & $21(65,6 \%)$ \\
Perempuan & $65,37 \pm 9,82$ & $63,84 \pm 7,35$ \\
Usia & $13,06 \pm 1,46$ & $12,44 \pm 0,87$ \\
Rerata Hasil Laboratorium Sebelum Operasi & $3,91 \pm 0,26$ & $3,87 \pm 0,30$ \\
Hemoglobin & & \\
Albumin & $10,29 \pm 1,14$ & $9,16 \pm 0,97$ \\
Rerata Hasil Laboratorium Setelah Operasi & $3,20 \pm 0,28$ & $3,10 \pm 0,40$ \\
Hemoglobin & $219,38 \pm 25,89$ & $377,50 \pm 46,14$ \\
Albumin & & \\
Jumlah Kehilangan Darah & $32(100 \%)$ & $0(0 \%)$ \\
Skor VAS Setelah Operasi & $0(0 \%)$ & $32(100 \%)$ \\
Rendah & & \\
Sedang & $0(0 \%)$ & $4(12,5 \%)$ \\
Kebutuhan Transfusi Darah & $32(100 \%)$ & $28(87,5 \%)$ \\
Ya & & $3(9,4 \%)$ \\
Tidak & $0(0 \%)$ & $29(90,6 \%)$ \\
Kebutuhan Transfusi Albumin & $32(100 \%)$ & \\
Ya & & \\
Tidak & & \\
\hline
\end{tabular}


TKR merupakan salah satu jenis operasi yang paling baik untuk menghilangkan nyeri dan mengembalikan fungsi dari lutut pada kondisi osteoarthritis terminal, tumor, trauma atau infeksi di sekitar sendi lutut. ${ }^{16-19}$ Risiko perdarahaan pada prosedur operasi sangat sulit untuk dihindari. Operasi ini berhubungan dengan kehilangan darah intra operasi dan setelah operasi, dengan jumlah yang dapat mencapai 1000-1500ml. ${ }^{20}$ Tindakan transfusi juga berisiko tinggi terjadi komplikasi. Oleh karena itu, pemberian terapi asam traneksamat dapat dipertimbangkan untuk menurunkan perdarahan. ${ }^{21}$

Yang et al. melaporkan bahwa injeksi intravena asam traneksamat dapat menurunkan jumlah kehilangan darah perioperative melalui penghitungan hemoglobin dan kebutuhan transfusi yang mana pada kelompok yang diberikan asam traneksamat hanya terdapat $40 \%$ yang membutuhkan transfusi darah. ${ }^{10}$ Trauma operasi setelah arthroplasty dapat menyebabkan keadaan hyperfibrinolytic. Benoni et al. juga melaporkan jumlah perdarahan dapat berkurang sebanyak 30$50 \% .{ }^{22}$ Penurunan pemberian transfusi darah ini sesuai pada penelitian ini yang mana pada kelompok pasien dengan asam traneksamat tidak membutuhkan transfusi darah pascaoperasi $(\mathrm{p}=0,113)$. Hasil ini sesuai karena perdarahaan setelah operasi merupakan mekanisme hemostatic dari fibrinolysis, maka obat anti fibrinolisis seperti asam traneksamat sangat efektif untuk mengatasi perdarahan..$^{23,24}$

Pada kelompok asam traneksamat dan kelompok tanpa asam traneksamat terdapat perbedaan rata-rata kadar hemoglobin setelah operasi yang signifikan secara statistik. Rata-rata kadar hemoglobin pada kelompok pasien dengan asam traneksamat lebih tinggi dibandingkan ratarata kadar hemoglobin tanpa asam traneksamat $(\mathrm{p}=0,000)$. Hasil ini sejalan dengan penelitian Yang et al. yang melaporkan pemeriksaan klinis dilakukan pada hari 1 hingga hari 3 setelah operatif sedangkan pemeriksaan lab seperti hemoglobin diperiksa 24 jam setelah operasi pada kelompok yang diberikan asam traneksamat memiliki rata-rata kadar hemoglobin yang lebih tinggi dari kelompok kontrol. ${ }^{10} \mathrm{Hal}$ ini membuktikan bahwa asam traneksamat dapat memberikan efek menurunkan perdaharan secara efektif karena perdarahan setelah operasi arthroplasty sering terjadi pada 24 jam pertama. ${ }^{16-19}$

Kadar albumin yang rendah dapat meningkatkan risiko komplikasi pada operasi total knee replacement. ${ }^{25}$ Pada hasil 
penelitian ini, tidak terdapat perbedaan ratarata kadar albumin setelah operasi yang signifikan secara statistik antara kelompok dengan asam traneksamat dan kelompok tanpa asam traneksamat $(\mathrm{p}=0,257 ; 95 \% \mathrm{CI}$ 0,27 - 0,07). Pada kedua kelompok tidak terdapat perbedaan yang signifikan untuk kadar albumin dan kebutuhan tranfusi albumin. Hal ini menunjukkan tidak ada risiko terjadinya komplikasi setelah dilakukan operasi TKR.

Pada hasil penelitian ini didapatkan perbedaan rata-rata jumlah kehilangan darah setelah operasi yang signifikan secara statistik antara kelompok asam traneksamat dengan kelompok tanpa asam traneksamat. Rata-rata jumlah kehilangan darah setelah operasi pada kelompok asam traneksamat lebih rendah dibandingkan rata-rata kelompok tanpa asam traneksamat $(\mathrm{p}=0,000)$. Hasil ini sejalan dengan Yang et al. yang melaporkan total volume kehilangan darah pada pasien yang diberikan injeksi asam traneksamat lebih rendah dibandingkan yang tidak diberikan asam traneksamat. ${ }^{10}$ Pada studi metaanalisis menunjukkan bahwa penggunaan asam traneksamat pada total knee replacement secara signifikan menurunkan jumlah kehilangan darah. Asam traneksamat menghambat aktivasi molekul plasminogen yang mencegah plasmin berikatan dengan fibrinogen dan struktur fibrin setelah terbentuk clot. $^{26}$

Hasil penelitian menunjukkan bahwa VAS score dengan kategori rendah paling banyak terdapat pada kelompok pasien yang diberikan terapi asam traneksamat $(\mathrm{p}=0,000)$. Jumlah perdarahan yang sedikit pada kelompok yang diberikan injeksi asam traneksamat dapat menjadi faktor berkurangnya rasa nyeri pada pasien. Hasil penelitian kami sejalan dari Grosso et al. ${ }^{27}$ serta pada penelitian Pauzenberger, et al ${ }^{28}$ dan Guerreiro ,et al ${ }^{29}$ yang melaporkan adanya penurunan rasa nyeri pada pasien yang dilakukan operasi TKR yang sebelumnya diberikan injeksi asam traneksamat yang penyebab yang paling memungkinkan adalah adanya penurunan post operatif hematoma pada fase awal di grup asam tranexamat ${ }^{28}$. Hematoma setelah operasi dapat menyebabkan peningkatan tekanan intrakompartemen. Hal ini dapat meningkatkan rasa nyeri pada pasien, sehingga VAS score pada pasien pun meningkat.Akan tetapi signifikansi lebih lanjut mengenai penurunan VAS ini harus lebih dianalisis lebih lanjut pada penelitian selanjutnya.

Setiap kelompok pada penelitian ini dioperasi oleh dokter orthopaedi yang sama sehingga teknik operasi yang dilakukan akan sama. Hal ini memberikan kekuatan pada penelitian ini sebab tidak ada faktor 
eksternal teknik operasi yang mengganggu pengamatan penelitian. Beberapa kekurangan dari penelitian ini antara lain jumlah sampel yang masih belum cukup, belum ada double blind dan randomisasi, jumlah jenis kelamin perempuan yang lebih tinggi pada penelitian ini, dan tidak ada data tentang penggunaan teknik anestesi intraoperatif. Jenis kelamin perempuan dapat memberikan tingkat hemoglobin sebelum operasi yang lebih rendah dan kebutuhan transfusi yang lebih tinggi. Penggunaan teknik anesthesia dapat mempengaruhi juga dalam total kehilangan darah.

Walaupun terdapat beberapa kekurangan, hasil dari penelitian ini menunjukkan bahwa penggunaan injeksi asam traneksamat pada operasi TKR dapat menurunkan jumlah kehilangan darah, sehingga kadar hemoglobin setelah operasi tidak turun banyak, kebutuhan transfusi darah berkurang, dan nyeri setelah operasi berkurang. Kadar albumin pada kelompok pasien yang diberikan asam traneksamat yang terevaluasi pada penelitian ini menurunkan risiko komplikasi pada operasi TKR.

\section{KESIMPULAN DAN SARAN}

Hasil pemberian injeksi asam traneksamat pada pasien yang menjalani operasi TKR di salah satu rumah sakit di Surabaya sejak April 2017 menunjukkan bahwa kelompok yang diberikan asam traneksamat memiliki kadar hemoglobin setelah operasi yang lebih tinggi dibanding kelompok yang tidak diberi asam traneksamat, tidak ada perbedaan yang signifikan dari kadar albumin setelah operasi pada kedua kelompok, pemberian asam traneksamat akan menurunkan jumlah kehilangan darah, menurunkan derajat nyeri yang terlihat dari skor VAS, dan berkurangnya kebutuhan transfusi darah setelah operasi TKR.

Saran untuk penilitian selanjutnya sebaiknya dilakukan dengan menggunakan jumlah sampel yang lebih besar. Studi yang dilakukan dapat berupa studi randomized double blind controlled trial sehingga dapat menurunkan bias dan error dalam penelitian.

\section{REFERENSI}

1. Ganvir SD, Zambare BR. Prevalence and identification of risk factors for knee osteoarthritis among elderly men and women. Sch J Applied Med Sci. 2013;1(6):700-703.

2. Yoo JJ, Kim DH, Kim HA. Risk factors for progression of radiographic knee osteoarthritis in elderly community residents in Korea. 2018:1-7.

3. Dang PP, Schwarzkopf R. Tranexamic acid and total knee arthroplasty. Ann Orthop Rheumatol. 2013;1(1):1001.

4. Cundy WJ, Theodoulou MA, Ling CM, et al. Blood Loss in Total Knee Arthroplasty. 2016;1(212). 
5. Da H, Pa C, Aj M, et al. Anti-fibrinolytic use for minimising perioperative allogeneic blood transfusion (Review). 2011;(1).

6. Roberts I, Shakur H, Afolabi A, et al. The importance of early treatment with tranexamic acid in bleeding trauma patients: an exploratory analysis of the CRASH-2 randomized controlled trial. Lancet (London, England). 2011; 377(9771):1096-1101, 1101-2.

7. Li ZJ, Zhao MW, Zeng L. Additional Dose of Intravenous Tranexamic Acid after Primary Total Knee Arthroplasty Further Reduces Hidden Blood Loss. 2018;131(6):638-643.

8. Dahuja A, Bhowmik S, Kaur R, Shayam R. Antifibrinolytic in reducing postoperative blood loss in total hip replacement and its effect on coagulation profile: A prospective randomized study. 2018:3-8.

9. Graven-Nielsen T, McArdle A, Phoenix J, Arendt-Nielsen L, Jensen TS, Jackson MJ, Edwards RH. In vivo model of muscle pain: quantification of intramuscular chemical, electrical, and pressure changes associated with salineinduced muscle pain in humans. Pain. 1997 Jan 1;69(1-2):137-43.

10. Fu DJ, Chen C, Guo L, Yang L. Use of intravenous tranexamic acid in total knee arthroplasty: a meta-analysis of randomized controlled trials. Chin $J$ Traumatol. 2013;16(2):67-76.

11. Yang ZG, Chen WP, Wu LD. Effectiveness and safety of tranexamic acid in reducing blood loss in total knee arthroplasty: a meta-analysis. J Bone Joint Surg Am. 2012;94(13):1-7.

12. Triyudanto AN, Lubis AMT. The effects of intra-articular tranexamic acid given intraoperatively and intravenous tranexamic acid given preoperatively on post surgical bleeding and transfusion rate post total knee arthroplasty. Med J Indones. 2016;25(4):234-239.

13. Breugem SJM, Haverkamp D. Anterior knee pain after a total knee arthroplasty:
What can cause this pain? World $J$ Orthop. 2014;5(3):163-170.

14. Kamath AF, Nelson CL, Elkassabany N, Guo Z, Liu J. Low albumin is a risk factor for complications after revision total knee arthroplasty. J Knee Surg. 2017;30(3):269-275.

15. Levitt DG, Levitt MD. Human serum albumin homeostasis: a new look at the roles of synthesis, catabolism, renal and gastrointestinal excretion, and the clinical value of serum albumin measurements. 2016.

16. Hawker G, Mian S, Kendzerska T, et al. Measures of adult pain. Arthritis Care Res. 2011;63(11):240-252.

17. Moghtadaei M, Shahoseini GR. Risk Factors for Blood Loss Following Total Knee Arthroplasty. 2014; 1(4):1-5

18. Banerjee S, Issa K, Kapadia BH, et al. Intraoperative non pharmacotherapeutic blood management strategies in total knee arthroplasty. $J$ Knee Surg. 2013;26:387-93.

19. José Wanderley Vasconcelos Gdava. Blood Loss in Total Knee Arthroplasty with and Without Tourniquet Release. 2011; 19(1):32-36.

20. Sahu S, Hemiata, Verma A. Adverse events related to blood transfusion. 2014; 58(5).

21. Schlenke P. Patient Blood Management: It is Time to Streamline. 2015:72-73.

22. Bower WF, Jin L, Underwood MJ, et al. Perioperative blood transfusion increases length of hospital stay and number of postoperative complications in non-cardiac surgical patients. Hong Kong Med J. 2010;16:116 20.

23. Kerakkanavar S, Venkatesh R, Gopinath KM, Pramodkumar M, Kerakkanavar S. Effect of intravenous tranexamic acid on blood loss and blood transfusion in total knee replacement: a prospective, randomized study in Indian population. Orthop JR. 2017; 3(5):916-921.

24. Xu J, Wang L, Ma X. Comparison of efficacy and safety of fibrin glue versus tranexamic acid for reducing blood loss in primary total knee arthroplasty: a 
systematic review and meta-analysis. 2016; 9(2):1236-1244.

25. Aslam KS, Niazi AK, Nabi O. Efficacy of tranexamic acid in reducing blood loss in total knee replacements S-211. 2015:210-214.

26. Kamath AF, Nelson CL, Elkassabany N, et al. Low albumin is a risk factor for complications after revision total knee arthroplasty. J Knee Surg 2017; 30(03): 269-275.

27. Grosso MJ, Trofa DP, Danoff JR, et al. Tranexamic acid increases early perioperative functional outcomes after total knee arthroplasty. Arthroplasty Today xxx (2017) 1e4.

28. Pauzenberger L, Domej MA, Heuberer PR, Hexel M, Grieb A, Laky B, Blasl J, Anderl W. The effect of intravenous tranexamic acid on blood loss and early post-operative pain in total shoulder arthroplasty. The bone \& joint journal. 2017 Aug;99(8):1073-9.

29. Guerreiro JP, Badaro BS, Balbino JR, Danieli MV, Queiroz AO, Cataneo DC. Application of Tranexamic Acid in Total Knee Arthroplasty-Prospective Randomized Trial. The open orthopaedics journal. 2017;11:1049. 